\title{
Performa Cacing Lumbricus rubellus terhadap Penambahan Tepung Cangkang Telur sebagai Media
}

\author{
Performance of Lumbricus rubellus towards Addition of Eggshell Powder as Media \\ N. C. Hartono*, A. M. Fuah, V. A. Mendrofa, \& Winarno \\ Departemen Ilmu Produksi dan Teknologi Peternakan, Fakultas Peternakan, Institut Pertanian Bogor \\ Jl. Agatis, Kampus IPB Darmaga Bogor 16680, Indonesia \\ *Corresponding author: nadia chrism@apps.ipb.ac.id \\ (Received 10-07-2021; Revised 13-09-2021; Accepted 20-09-2021)
}

\begin{abstract}
Lumbricus rubellus is one of earthworm species that has been cultivated because its utility as feed for livestock and fish. The culture media for earthworms are mainly manure and compost. The purpose of this research was to observe the performance of Lumbricus rubellus given eggshell powder in different types and levels. This study used commercial eggshell flour and homemade eggshell flour with different levels $(10 \%, 20 \%, 30 \%)$ mixed with cow dung as a medium. The results of the study showed that the addition of eggshell flour (commercial and homemade) as much as $\mathbf{1 0 \%}$ showed a higher earthworm weight gain than other treatments but the cocoon production of the treatment was lower than the control $(0 \%$ eggshell flour).
\end{abstract}

Keywords: eggshell powder, Lumbricus rubellus, performance

\begin{abstract}
ABSTRAK
Lumbricus rubellus adalah salah satu spesies cacing tanah yang sudah banyak dibudidaya karena kegunaannya sebagai bahan pakan ternak dan ikan. Media pemeliharaan cacing tanah yang optimal adalah kotoran ternak dan kompos. Tujuan dari penelitian ini adalah untuk mengamati performa dari Lumbricus rubellus setelah diberi tepung cangkang telur dengan jenis dan persentase yang berbeda. Penelitian ini menggunakan tepung cangkang telur komersial dan tepung cangkang telur buatan sendiri dengan taraf yang berbeda (10\%, 20\%, 30\%) yang dicampur dengan kotoran sapi sebagai media. Hasil dari penelitian menunjukkan bahwa penambahan tepung cangkang telur (komersial dan buatan sendiri) sebanyak $\mathbf{1 0 \%}$ menunjukkan pertambahan bobot cacing tanah yang lebih tinggi dari perlakuan lainnya tetapi produksi kokon perlakuan tersebut lebih rendah dari kontrol (tepung cangkang telur $0 \%$ ).
\end{abstract}

Kata kunci: Lumbricus rubellus, performa, tepung cangkang telur

\section{PENDAHULUAN}

Cacing tanah merupakan salah satu hewan invertebrata yang memiliki kemampuan dan manfaat yang menguntungkan bagi kehidupan manusia. Kemampuan yang dimiliki oleh cacing tanah berupa mendekomposisi material organik yang ada di tanah, mengaduk material organik dan anorganik di dalam tanah, dan meningkatkan kesuburan tanah karena keberadaan cacing tanah meningkatkan kandungan nitrogen dalam tanah (Edwards dan Lofty 1972). Pemanfaatan cacing tanah yang dapat menghasilkan keuntungan secara ekonomi berupa pemanfaatan sebagai bahan pakan ternak, ikan, dan hewan peliharaan, bahan obat-obatan, bahan kosmetik, dan casting cacing tanah dapat dimanfaatkan untuk pertanian
(Sihombing 2000). Genus cacing tanah yang sudah banyak dipelajari umumnya berasal dari famili Megascolicidae dan Lumbricidae yang terdiri atas Lumbricus, Eiseinia, Pheretima, Perionyx, Diplocardi dan Lidrillus.

Cacing tanah Lumbricus rubellus merupakan salah satu spesies yang biasa dibudidayakan dan diperjualbelikan karena manfaatnya sebagai pakan ternak dan ikan dan harganya juga murah (Yulius et al. 2015). Cacing tanah ini mempunyai banyak kelebihan dibanding cacing jenis lain. Kelebihan dari cacing ini adalah tidak berbau, cepat berkembang biak, tumbuh subur, mempunyai ketahanan hidup yang tinggi, mudah beradaptasi dengan berbagai media yang dipergunakan, dan sangat mudah dibudidaya (Rusmini et al. 2016). Kelebihan dari cacing tanah oleh faktor lingkungan 
(media). Faktor-faktor yang mempengaruhi kehidupan cacing tanah di habitat alami adalah antara lain suhu (temperatur), kelembaban $(\mathrm{rH})$, keasaman $(\mathrm{pH})$ dan ketersediaan bahan organik (Hanafiah et al. 2010). Bahan organik yang sering digunakan sebagai media budidaya cacing tanah adalah kotoran ternak dan kompos tanaman.

Telur merupakan salah satu bahan pangan sumber protein hewan yang banyak dikonsumsi masyarakat. Pertumbuhan penduduk yang terus meningkat menyebabkan permintaan telur juga mengalami peningkatan. Produksi telur ayam di Indonesia pada tahun 2019 mencapai 4.753.382,23 ton (BPS 2020). Konsumsi dan produksi telur akan berdampak pada peningkatan produksi limbah telur, seperti cangkang telur. Pengelolaan untuk mengurangi limbah cangkang telur biasanya dilakukan dengan pemanfaatan cangkang telur menjadi bahan pembuatan pupuk dan kerajinan tangan.

Pemanfaatan lainnya dari cangkang telur diolah menjadi tepung cangkang telur yang berguna sebagai bahan pakan hewan. Pembuatan tepung cangkang telur tersebut didasari oleh cangkang telur mengandung unsur mineral yang tinggi dan protein yang masih dapat digunakan. Unsur mineral dari cangkang telur juga berguna untuk meningkatkan kualitas pupuk hasil pengomposan. Kandungan unsur mineral dari cangkang telur menurut Putri dan Nugroho (2017) terdiri atas $\mathrm{CaCO} 3$ 98,43\%, MgCO3 0,84\%, dan Ca3(PO4)2 0,75\%. Menurut Garcia-Montero et al. (2013), unsur kalsium pada tanah bermanfaat bagi semua spesies cacing tanah dari famili Lumbricidae karena adanya kelenjar calciferous yang dapat memproduksi granula kalsit. Fungsi granula kalsit adalah untuk menaikkan $\mathrm{pH}$ dan kalsium karbonat pada media atau tanah (Garcia-Montero et al. 2013). Tepung cangkang telur memiliki potensi untuk menjadi bahan tambahan media cacing tanah karena kandungan mineral dan protein di dalamnya dapat dimanfaatkan oleh cacing tanah sehingga perlu untuk mengamati performa cacing tanah Lumbricus rubellus dengan penambahan tepung cangkang telur sebagai media dengan persentase yang berbeda.

\section{MATERI DAN METODE}

\section{Materi}

Materi yang digunakan adalah cacing tanah (Lumbricus rubellus), kotoran sapi, cangkang telur ayam ras buatan sendiri (TTB), tepung cangkang telur komersial (TTK), dan air. Lumbricus rubellus disiapkan sebanyak $1050 \mathrm{~g}$ dengan umur satu bulan dua minggu. Alat yang digunakan adalah wadah pemeliharaan berbentuk kotak dengan ukuran $38 \mathrm{~cm} \times 30 \mathrm{~cm} \times 12 \mathrm{~cm}$, sarung tangan, sekop mini, botol penyemprot air, timbangan digital, termometer dan higrometer digital, oven, blender, terpal karung, dan alat tulis.

\section{Metode}

Metode dari penelitian ini terdiri atas lima tahapan. Berikut merupakan tahapan-tahapan yang dilakukan sebelum dan selama berlangsungnya penelitian.

Persiapan media hidup (Sihombing 2002). Kotoran sapi disiapkan sesuai kebutuhan dan dikeringkan minimal selama dua minggu. Kotoran sapi yang sudah dikeringkan dan tepung cangkang telur masing-masing ditimbang sesuai dengan perlakuan dan kedua bahan tersebut dicampurkan. Semua media perlakuan beratnya sama yaitu $1 \mathrm{~kg}$ di awal pemeliharaan.

Induksi cacing tanah pada media (Sihombing 2002). Wadah berisi media dari kotoran sapi dan tepung cangkang telur disiapkan dan cacing tanah disebar di atas media. Cacing disebar sebanyak $50 \mathrm{~g}$ untuk masing-masing wadah perlakuan. Pergerakan cacing tanah untuk masuk ke dalam media memerlukan waktu. Wadah media dengan cacing tanah yang sudah masuk ke dalam media diberi penutup seperti karung atau kain.

Penambahan media (Sihombing 2002). Penambahan media baru pada cacing tanah dilakukan setiap seminggu sekali. Jumlah media yang ditambahkan sebanyak berat media awal. Berat media yang ditambahkan sebesar 200 gram per minggunya.

Pengamatan dan pengambilan data. Peubah yang diamati dari penelitian ini adalah pertambahan bobot, jumlah segmen cacing tanah dari kepala hingga klitelum, dan jumlah kokon. Pertambahan bobot, jumlah segmen cacing tanah dari klitelum hingga kepala, dan jumlah kokon dihitung setiap seminggu sekali selama 4 minggu. Kelembaban media diperhatikan dengan penyemprotan air dilakukan setiap hari dengan jumlah semprotan disesuaikan dengan kebutuhan. Semua perlakuan menerima jumlah semprotan air yang sama.

\section{Analisis Data}

Rancangan penelitian yang digunakan pada penelitian ini adalah Rancangan Acak Lengkap. Perlakuan media pemeliharaan Lumbricus rubellus yang dilakukan dalam penelitian dapat dilihat pada Tabel 1. Model rancangan percobaan yang digunakan adalah sebagai berikut:

$$
Y i j=\mu+\tau i+\beta j+\varepsilon i j
$$

Keterangan

$$
\begin{array}{ll}
\text { Yij } & =\text { pengamatan pada perlakuan ke-I, ulangan ke-j } \\
\mu & =\text { rataan umum } \\
\tau \mathrm{i} & =\text { pengaruh perlakuan ke-i } \\
\varepsilon \mathrm{ij} & =\text { galat percobaan perlakuan ke-i, ulangan ke-j }
\end{array}
$$

Tabel 1. Perlakuan pada media pemeliharaan cacing Lumbricus rubellus

\begin{tabular}{cccc}
\hline Perlakuan & S $(\%)$ & TTB $(\%)$ & TTK $(\%)$ \\
\hline P0 (Kontrol) & $100 \%$ & - & - \\
P1 & 90 & 10 & - \\
P2 & 80 & 20 & - \\
P3 & 70 & 30 & - \\
P4 & 90 & - & 10 \\
P5 & 80 & - & 20 \\
P6 & 70 & - & 30 \\
\hline
\end{tabular}

$\mathrm{S}=$ Media dari kotoran sapi; TTB $=$ Tepung cangkang telur buatan sendiri; TTK $=$ Tepung cangkang telur komersial 
Pengolahan data dilakukan dengan software IBM SPSS Statistics 24.0 untuk analisis varian satu arah sidik ragam dengan tingkat signifikansi $(\alpha=0.05)$. Uji dilanjutkan dengan uji Tukey HSD dilakukan apabila terdapat perbedaan signifikan pada data yang diperoleh (Sudarwati et al. 2019).

\section{HASIL DAN PEMBAHASAN}

\section{Pertambahan Bobot Badan Lumbricus rubellus}

Data pertambahan bobot cacing tanah L. rubellus selama empat minggu pemeliharaan disajikan dalam Tabel 2. Berdasarkan hasil analisis, penambahan tepung cangkang telur pada media cacing tanah dengan jenis dan persentase yang berbeda dapat mempengaruhi pertambahan bobot cacing tanah L. rubellus $(\mathrm{P}<0.05)$. Rata-rata pertambahan bobot cacing tanah perlakuan tepung cangkang telur $10 \%$ lebih besar dari perlakuan $20 \%$ dan $30 \%$.

Penambahan tepung cangkang telur dengan jenis dan persentase yang berbeda menyebabkan karakteristik media yang berbeda dari masing-masing perlakuan. Semakin banyak tepung cangkang telur yang diberikan, semakin kering media cacing tanahnya dan sebaliknya. Berdasarkan hasil penelitian, perlakuan media dengan tepung cangkang telur komersial sebanyak 30\% menyebabkan bobot cacing tanah terus mengalami penurunan dari minggu pertama sehingga perlakuan ini memiliki bobot paling rendah pada minggu keempat yaitu sebesar 39.27 gram. Hal ini disebabkan oleh persediaan pakan yang kurang, kelembaban media yang terlalu tinggi, dan faktor umur. Menurut Manurung et al. (2014), penurunan bobot cacing tanah dapat disebabkan oleh faktor umur dan nutrisi yang terus berkurang setiap harinya.

Pertambahan bobot yang paling tinggi terjadi pada perlakuan TTB 10\% dan diikuti oleh perlakuan TTK 10\% dengan masing-masing pertambahan bobot sebesar 11.61 gram dan 10.07 gram dan lebih besar dari perlakuan kontrol. Hal ini dapat disebabkan oleh kandungan nutrisi dari tepung cangkang telur yang dibutuhkan oleh cacing. Cacing tanah membutuhkan nutrisi berupa bahan karbon organik yang bisa berupa karbohidrat, protein, dan lemak. Kandungan cangkang telur terdiri atas $95.1 \%$ bahan anorganik, 3.3\% protein, dan $0.03 \%$ lemak (Sitorus 2009).
Pertambahan bobot cacing tanah pada perlakuan TTB dibandingkan dengan perlakuan TTK pada persentase yang sama menunjukkan pertambahan bobot yang berbeda. Hal ini disebabkan karena tepung cangkang telur buatan sendiri dan tepung cangkang telur komersial memiliki kehalusan yang berbeda. Tepung cangkang telur buatan sendiri teksturnya lebih kasar dari tepung cangkang telur komersial karena adanya perbedaan dalam proses pengolahan pada tahapan pengeringannya. Tepung cangkang telur yang dibuat sendiri juga mengandung tambahan nutrisi dari selaput cangkang telur yang juga diolah bersamaan dengan cangkang telur. Kandungan selaput cangkang telur terdiri atas bahan nitrogen sebesar 15.3-15.8\% dan karbohidrat sebesar di bawah 4\% dari bahan kering (Balch dan Cooke 1970). Kandungan dari tepung cangkang telur komersial terdiri atas 94\% kalsium karbonat, 1\% magnesium karbonat, $1 \%$ kalsium fosfat, dan $4 \%$ protein.

\section{Jumlah Segmen Lumbricus rubellus}

Data jumlah segmen dari klitelum hingga kepala cacing tanah L. rubellus selama 4 minggu pemeliharaan disajikan dalam Tabel 3. Jenis dan persentase tepung cangkang telur memengaruhi jumlah segmen dari Lumbricus rubellus $(\mathrm{P}<0.05)$. Rata-rata jumlah segmen dari perlakuan $10 \%$ tepung cangkang telur lebih besar dari ratarata perlakuan $20 \%$ dan $30 \%$. Berdasarkan hasil penelitian, diperoleh jumlah segmen dari klitelum hingga kepala dengan rata-rata antara 27.50-31.87 segmen. Berdasarkan penelitian Mambrasar et al. (2018) letak klitelum pada Lumbricus rubellus adalah pada segmen ke-27 sampai ke32. Beberapa spesies cacing tanah jumlah segmen saat lahir hingga dewasa tidak berubah contohnya Eisenia foetida dan spesies lainnya mengalami pertambahan segmen saat bertumbuh contohnya Allolobhopora chlorotica Sav. dan Eisenia Rosea Sav (Evans 1946; Edwards dan Lofty 1972).

Jumlah segmen tertinggi terjadi pada perlakuan tepung cangkang telur komersial $10 \%$ dan terendah pada perlakuan tepung cangkang telur komersial 30\%. Rata-rata jumlah segmen pada perlakuan tepung cangkang telur $10 \%$ dan $20 \%$ lebih tinggi dari perlakuan $30 \%$. Hal ini dapat disebabkan oleh kondisi media dengan perlakuan 30\% tepung cangkang telur terlalu kering dan memengaruhi jumlah segmen dari cacing tanah. Jenis tepung cangkang

Tabel 2. Pertambahan bobot (gram) cacing tanah Lumbricus rubellus selama empat minggu

\begin{tabular}{|c|c|c|c|c|c|c|c|c|}
\hline \multicolumn{2}{|c|}{ Perlakuan } & \multicolumn{5}{|c|}{ Bobot (g) Minggu ke- } & \multirow[t]{2}{*}{ Rata-rata (g) } & \multirow[t]{2}{*}{$\operatorname{PBB}(g)$} \\
\hline & & 0 & 1 & 2 & 3 & 4 & & \\
\hline Kontrol & $\mathrm{P} 0$ & 50.00 & 52.17 & 67.17 & 58.53 & 52.43 & 57.58 & 7.58 \\
\hline \multirow[t]{3}{*}{ TTB } & $\mathrm{P} 1$ & 50.03 & 58.47 & 74.40 & 60.53 & 53.17 & $61.64 \mathrm{a}$ & $11.61 \mathrm{a}$ \\
\hline & $\mathrm{P} 2$ & 49.97 & 54.40 & 65.53 & 53.10 & 46.77 & $54.95 b$ & 4.98 \\
\hline & P3 & 49.97 & 54.27 & 58.33 & 47.47 & 42.07 & $50.53 \mathrm{c}$ & 0.57 \\
\hline \multirow[t]{3}{*}{ TTK } & $\mathrm{P} 4$ & 50.07 & 53.43 & 66.10 & 63.37 & 57.63 & $60.13 a$ & $10.07 \mathrm{a}$ \\
\hline & P5 & 50.00 & 58.63 & 56.87 & 49.27 & 39.37 & $51.03 \mathrm{~b}$ & 1.03 \\
\hline & P6 & 50.10 & 48.80 & 48.43 & 35.20 & 24.63 & $39.27 \mathrm{c}$ & -10.83 \\
\hline
\end{tabular}

Keterangan: TTB = tepung cangkang telur buatan sendiri; TTK = tepung cangkang telur komersial. Huruf kecil yang berbeda pada nilai kolom yang sama menandakan berbeda nyata $(\mathrm{P}<0.05)$. 
Hartono et al.

Jurnal Ilmu Produksi dan Teknologi Hasil Peternakan 9 (3): 158-162

Tabel 3. Jumlah segmen cacing tanah Lumbricus rubellus selama empat minggu

\begin{tabular}{|c|c|c|c|c|c|c|}
\hline \multicolumn{2}{|c|}{ Perlakuan } & \multicolumn{4}{|c|}{ Jumlah Segmen Minggu ke- } & \multirow[t]{2}{*}{ Rata-rata } \\
\hline & & 1 & 2 & 3 & 4 & \\
\hline Kontrol & $\mathrm{P} 0$ & 29.20 & 30.80 & 31.77 & 31.37 & $30.78 \pm 0.12$ \\
\hline \multirow[t]{3}{*}{ ТTВ } & $\mathrm{P} 1$ & 30.73 & 31.00 & 31.03 & 31.23 & $31.00 \pm 0.21 \mathrm{a}$ \\
\hline & $\mathrm{P} 2$ & 30.50 & 31.03 & 30.47 & 31.87 & $30.97 \pm 0.65 \mathrm{ab}$ \\
\hline & P3 & 30.33 & 31.33 & 30.63 & 31.37 & $30.92 \pm 0.07 b$ \\
\hline \multirow[t]{3}{*}{ TTK } & $\mathrm{P} 4$ & 30.37 & 31.13 & 31.27 & 31.30 & $31.02 \pm 0.43 \mathrm{a}$ \\
\hline & P5 & 29.87 & 31.10 & 31.37 & 30.67 & $30.75 \pm 0.55 \mathrm{ab}$ \\
\hline & P6 & 27.50 & 30.27 & 31.20 & 31.57 & $30.13 \pm 0.81 b$ \\
\hline
\end{tabular}

Keterangan: TTB = tepung cangkang telur buatan sendiri; TTK = tepung cangkang telur komersial. Huruf kecil yang berbeda pada nilai kolom yang sama menandakan berbeda nyata $(\mathrm{P}<0.05)$.

telur yang berbeda dapat memengaruhi jumlah segmen karena kondisi media TTK yang lebih kering dari TTB pada persentase jumlah tepung cangkang telur yang sama. Perbedaan jumlah klitelum yang diperoleh juga dapat disebabkan oleh kesalahan dalam perhitungan karena pada beberapa cacing tanah segmen pada bagian klitelum tidak terlalu telihat jelas akibat warnanya yang terlalu pucat dan adanya kerusakan segmen.

\section{Jumlah Kokon yang Diproduksi oleh Lumbricus rubellus}

Hasil analisis data jumlah kokon (Tabel 4) menunjukkan bahwa faktor persentase jumlah tepung cangkang telur memengaruhi jumlah kokon $(\mathrm{P}<0.05)$. Ratarata perlakuan $10 \%$ tepung cangkang telur lebih besar dari rata-rata perlakuan $20 \%$ dan $30 \%$. Rata-rata jumlah kokon tertinggi terjadi pada kontrol sebanyak 29.42 kokon dan rata-rata jumlah kokon terendah terjadi pada perlakuan media dengan tepung cangkang telur komersial sebanyak $30 \%$ dengan rata-rata 0.08 kokon. Media perlakuan tepung cangkang telur komersial sebanyak 30\% merupakan media yang kondisinya paling kering sedangkan media kontrol kondisinya paling lembab. Faktor lingkungan yang memengaruhi proses pertumbuhan dan perkembangbiakan cacing tanah adalah temperatur, $\mathrm{pH}$, kadar air tanah, dan jenis pakan (Manurung et al. 2014).
Penurunan jumlah kokon di minggu ketiga dan keempat pada kontrol dan perlakuan TTB 10\% berhubungan dengan turunnya bobot cacing tanah di minggu ketiga dan keempat. Faktor yang menyebabkan penurunan bobot cacing tanah dapat disebabkan oleh faktor pakan, kelembaban, dan umur selain itu ketiga faktor tersebut juga dapat memengaruhi tingkat mortalitas cacing tanah. Menurut Suthar (2007), laju produksi kokon yang berbeda dari cacing tanah dapat disebabkan oleh variasi kualitas media dan kandungan bahan kimia dari pakan merupakan faktor penting dalam proses pemeliharaan cacing tanah. Laju produksi kokon dipengaruhi oleh kandungan nitrogen pada media (Suthar 2007; Bhat 2015). Penurunan jumlah kokon pada penelitian ini disebabkan oleh penurunan kualitas media dan kandungan nitrogen dalam media.

\section{KESIMPULAN}

Penambahan tepung cangkang telur pada media dapat meningkatkan performa cacing tanah Lumbricus rubellus. Taraf penambahan tepung cangkang telur (10\%) pada media cacing Lumbricus rubellus lebih baik pada pertambahan bobot badan, jumlah segmen dan jumlah kokon yang diproduksi.

Tabel 4. Jumlah kokon cacing tanah Lumbricus rubellus selama empat minggu

\begin{tabular}{ccccccc}
\hline \multirow{2}{*}{ Perlakuan } & & \multicolumn{3}{c}{ Jumlah Kokon per Minggu } & \multicolumn{2}{c}{ Rata-rata (Butir) } \\
\cline { 3 - 6 } & & 1 & 2 & 3 & 4 & $29.42 \pm 03.46$ \\
\hline \multirow{2}{*}{ Kontrol } & P0 & 18.33 & 63.33 & 25.67 & 10.33 & $17.75 \pm 10.42 \mathrm{a}$ \\
TTB & P1 & 10.33 & 30.67 & 21.67 & 8.33 & $9.92 \pm 4.34 \mathrm{ab}$ \\
& P2 & 7.33 & 10.00 & 16.00 & 6.33 & $2.83 \pm 0.50 \mathrm{c}$ \\
& P3 & 2.00 & 1.67 & 0.67 & 7.00 & $18.25 \pm 10.71 \mathrm{a}$ \\
TTK & P4 & 13.00 & 24.00 & 29.00 & 7.00 & $2.25 \pm 1.41 \mathrm{~b}$ \\
& P5 & 5.00 & 0.33 & 3.67 & 0.00 & $0.08 \pm 0.01 \mathrm{c}$ \\
\hline
\end{tabular}

Keterangan: TTB = tepung cangkang telur buatan sendiri; TTK = tepung cangkang telur komersial. Huruf kecil yang berbeda pada nilai kolom yang sama menandakan berbeda nyata $(\mathrm{P}<0.05)$. 


\section{DAFTAR PUSTAKA}

Balch, D. A. \& R. A. Cooke. 1970. A study of the composition of hen's egg-shell membranes. Ann. Biol. anim. Bioch. Biophys. 10(2):13-25.

Bhat, S. A., J. Singh, \& A. P. Vig. 2015. Potential utilization of bagasse as feed material for earthworm Eisenia fetida and production of vermicompost. Springer Plus. 4(11):1-9.

BPS (Badan Pusat Statistik). 2020. Produksi Telur Ayam Petelur Menurut Provinsi, 2009-2019. Badan Pusat Statistik Indonesia, Jakarta.

Edwards, C. A. \& J. R. Lofty. 1972. Biology of Earthworms. Chapman and Hall Ltd., London.

Evans, A. C. 1946. Distribution of number of segments in earthworms and its significance. Nature. 158:98-99.

Garcia-Montero, L. G., M. A. Grande-Ortiz, I. ValverdeAsenjo, C. Menta, \& I. Hernando. 2013. Impact of earthworm casts on soil $\mathrm{pH}$ and calcium carbonate in black truffle burns. Agroforestry Sys. 87(4):815-826.

Hanafiah, K. A., A. Napoleon, \& N. Ghofar . 2010. Biologi Tanah Ekologi \& Makrobiologi Tanah. Raja Grafindo Press, Jakarta.

Mambrasar, R. E., K. Krey, \& S. Ratnawati. 2018. Keanekaragaman, kerapatan, dan dominansi cacing tanah di bentang alam Pegunungan Arfak. Vogelkop 1(1):22-30.

Manurung R. J., Yusfiati, \& D. I. Roslim. 2014. Pertumbuhan cacing tanah (Perionyx excavatus) pada dua media. JOM FMIPA. 1(0):291-302.
Putri, F. L. N., \& R. P. Nugroho. 2017. Analisa kandungan kalsium pada serbuk cangkang telur ayam hasil pengeringan dan kalsinasi. Tesis. Akademi Farmasi Putera Indonesia, Malang.

Rusmini, N. Kusumawati, M. A. Prahara, \& P. R. Wikandari. 2016. Pelatihan Budidaya Caing Tanah (Lumbricus rubellus) bagi para tani Desa Sumberdukun, Ngariboyo, Magetan. Jurnal ABDI 1(2):114-120.

Sihombing D. T. H. 2000. Potensi cacing tanah bagi sektor industri dan pertanian. Med. Pet. 23(1):1-13.

Sihombing D. T. H. 2002. Satwa Harapan I : Pengantar Ilmu Produksi dan Teknologi Budidaya. Pustaka Wirausaha Muda - Press, Bogor.

Sitorus J. P. 2009. Pemanfaatan pemberian tepung cangkang telur ayam ras dalam ransum terhadap performans burung puyuh (Cortunix cortunix japonica) umur 0-42 hari. Skripsi. Universitas Sumatera Utara, Medan.

Sudarwati, H., M. H. Natsir, \& V. M. A. Nurgiartiningsih. 2019. Statistika dan Rancangan Percobaan: Penerapan dalam Bidang Peternakan. UB Press, Malang.

Suthar, S. 2007. Vermicomposting potential of Perionyx sansibaricus (Perrier) in different waste materials. Bio. Tech. 98(6):1231-1237.

Yulius, N. Asmani, I. Alamsyah, L. Husin, \& H. Malini. 2015. Introduksi tehnik budidaya cacing Lumbricus rubellus dengan media kotoran ternak untuk mendukung desa mandiri lestari pangan di Desa Pelabuhan Dalam Kecamatan Pemulutan Kabupaten Ogan Ilir. Jurnal Pengabdian Sriwijaya. 3(1):229-240. 